Uluslararası Mühendislik

Cilt/Volume:12 Sayı/Issue:1 Ocak/January 2020

Araştırma Makalesi / Research Article

\title{
Sintering and Characterization of SiC Reinforced Ni Powders in Microwave Furnace
}

\begin{abstract}
Ahmet Yönetken*1 iD, Ayhan Erol ${ }^{2}$
${ }^{1}$ Afyon Kocatepe University, Faculty of Engineering, Electrical Engineering, ANS campus, 03200, Afyonkarahisar, TURKEY

${ }^{2}$ Afyon Kocatepe University, Faculty of Technology, Metalurgy and Materials Engineering, ANS campus, O3200, Afyonkarahisar, TURKEY

Kabul / Accepted: $30 / 07 / 2019$

Çevrimiçi Basım / Published Online: 04/11/2019

Son Versiyon/Final Version: 31/01/2020

Abstract

In this study, $\mathrm{SiC}$ reinforced nickel matrix composites, microwave at different temperatures It is produced by sintering in oven. Nickel deposition on $\mathrm{SiC}$ powders was achieved by using electroless nickel plating technique. It is sintered at temperatures between $500^{\circ} \mathrm{C}, 600{ }^{\circ} \mathrm{C}, 700^{\circ} \mathrm{C}, 800^{\circ} \mathrm{C}$ and $900^{\circ} \mathrm{C}$ under Ar atmosphere. XRD, SEM (Scanning Electron Microscope), pressure test and hardness measurements were used to characterize the properties of sintered samples in microwave furnace. The experimental results, maximum compressive strength ( omax) and hardness (HV) were carried out at $800{ }^{\circ} \mathrm{C}$. Microwave sintering of $\mathrm{Ni}$-coated $\mathrm{SiC}$ powders without electric current can be a promising technique for producing ceramic-reinforced nickel composites.
\end{abstract}

\section{Key Words}

"Microwave sintering, Powder metallurgy, Composites, Nickel plating" 


\section{Introduction}

Composite materials are being used with increasing speed in many advanced engineering applications (Yönetken 2018; Tang et al. 2003; Zang et al. 2005; Wu et al. 2014;Jarząbek et al. 2017). Powder Metallurgy is a more advantageous production technique compared to other production methods in terms of producing high-tech materials, high strength starting from powdered raw materials, less error, cheaper processes and providing physical and chemical properties of desired powders (Malecki and MicekIlnicka 2000; Söyler 2007). Electroless plated nickel plating has been widely used in many areas. Because of electrolysis plating technique, non-homogenous coating is achieved. High hardness, abrasion resistance and corrosion resistance high performance products were obtained in Ni coated composite samples. Electroplating Ni coating is a simple process with low cost. It can also be used in the surface coating of particles with a complex shape. This feature has been preferred in the industry coating method. (Zhangat All, 2015).

Ceramic-Metal composites reinforced with silicon carbide ( $\mathrm{SiC}$ ) are a well-known and commonly used material in applications. However, $\mathrm{SiC}$ is susceptible to $\mathrm{SiO}_{2}$ conversion very quickly in the oxygen environment due to its poor condensation and high decomposition. Due to the high cost of produced samples, its commercial success is limited (Mandal at All., 2001). Microwave furnaces (MWs) are electromagnetic waves operating at frequencies ranging from $300 \mathrm{MHz}$ to $300 \mathrm{GHz}$, and wave frequencies ranging from a few $\mathrm{cm}$ to several $\mathrm{mm}$. Unlike conventional heating, the penetration of microwave signals into materials causes a volumetric distributed heat source. As a result, the microwave sintering method enables faster heating of both small and large samples compared to conventional heating (Chatterjee at All., 1998).

Silicon carbide, which has many good properties such as good thermal conductivity, electrical conductivity, chemical stability, high mechanical strength and low friction, can be used as both structured materials and functional materials (Chen, All., 2003).

SiC-containing ceramic metal composites have higher thermal properties and chemical stability (Somiya at All, 2003).

SiC powder interacts with microwave frequency radiation at ambient temperature. The energy of the electromagnetic field changes into heat energy (Horatiu at All., 2007).

In this study, the production of SiC carbide doped ceramic-metal composites and production of the composite was performed using microwave sintering technique. Composites produced by applying physical and mechanical tests to the produced samples were characterized.

\section{Preparation of Sample}

\subsection{Material}

In this study, two different aspects were used. Firstly, $\mathrm{SiC}$ powders and Ni powders were mixed in a constant speed mixer for 24 hours to ensure a homogeneous mixture. silicon carbide ( $\mathrm{SiC}$ ), ceramic powder and metal as Nickel (Ni) powder. SiC powders of $10 \mu \mathrm{m}$ and $99.5 \%$ purity and $\mathrm{Ni}$ powders of $3 \mu \mathrm{m}$ and $99.5 \%$ purity were used, both of which were obtained from Johnson Matthey Materials Technology. The aim of this study is to reinforce SiC ceramic powders with Ni. Pure nickel was obtained from which $\mathrm{Ni}$ powders can be added directly in the mixture or can be obtained by coating with nickel chloride $\left(\mathrm{NiCl}_{2} .6 \mathrm{H}_{2} \mathrm{O}\right)$ which is used in the electroplating nickel plating bath (Sverdel At All., 1995) (Changhong, at All., 1997).

\subsection{Method}

In the experimental study, samples were prepared by two different methods. In the first method, the homogeneous mixture obtained by mixing SiC-Ni powders for a 24 hour period was formed as cold under 300 bar in the uniaxial hydraulic press and made ready for sintering. In the second method, silicon carbide powders were deposited on Ni SiC powders using electroless nickel plating technique. Then, it was shaped under uniaxial hydraulic press under pressure of 300 bar. The shaped raw samples were sintered in the industrial microwave sintering furnace for one hour in the temperature range of $500-900^{\circ} \mathrm{C}$ under an atmosphere of argon gas. Sintered samples were sanded and polished for mechanical and metallographic analysis. $20 \% \mathrm{SiC}$ powders were used by weight, Nickel Chloride, Ammonia, Hydrazine hydrate and pure water were used in the Ni-bath without electricity. The content of the coating bath is given in Table 1.

Table 1. The chemicals of Nickel plating bath and their ratios

\begin{tabular}{lc}
\hline \multicolumn{1}{c}{ Chemicals } & Raito \\
\hline Silicon Carbide $(\mathrm{SiC})$ & 6 \\
Nickel Chloride $\left(\mathrm{NiCI}_{2} \cdot 6 \mathrm{H}_{2} \mathrm{O}\right)$ & 96 \\
Hydrazine Hydrate $\left(\mathrm{N}_{2} \mathrm{H}_{4} \cdot \mathrm{H}_{2} \mathrm{O}\right)$ & $20 \%$ \\
Distiled Water & $80 \%$ \\
Temperature $\left({ }^{\circ} \mathrm{C}\right)$ & $90-95^{\circ} \mathrm{C}$ \\
pH Value & $9-10$ \\
\hline
\end{tabular}

Nickel plated silicon carbide powders were purified from chemicals by washing with pure water after plating and made ready for subsequent processing. The experiment flowchart is shown in Figure 1 


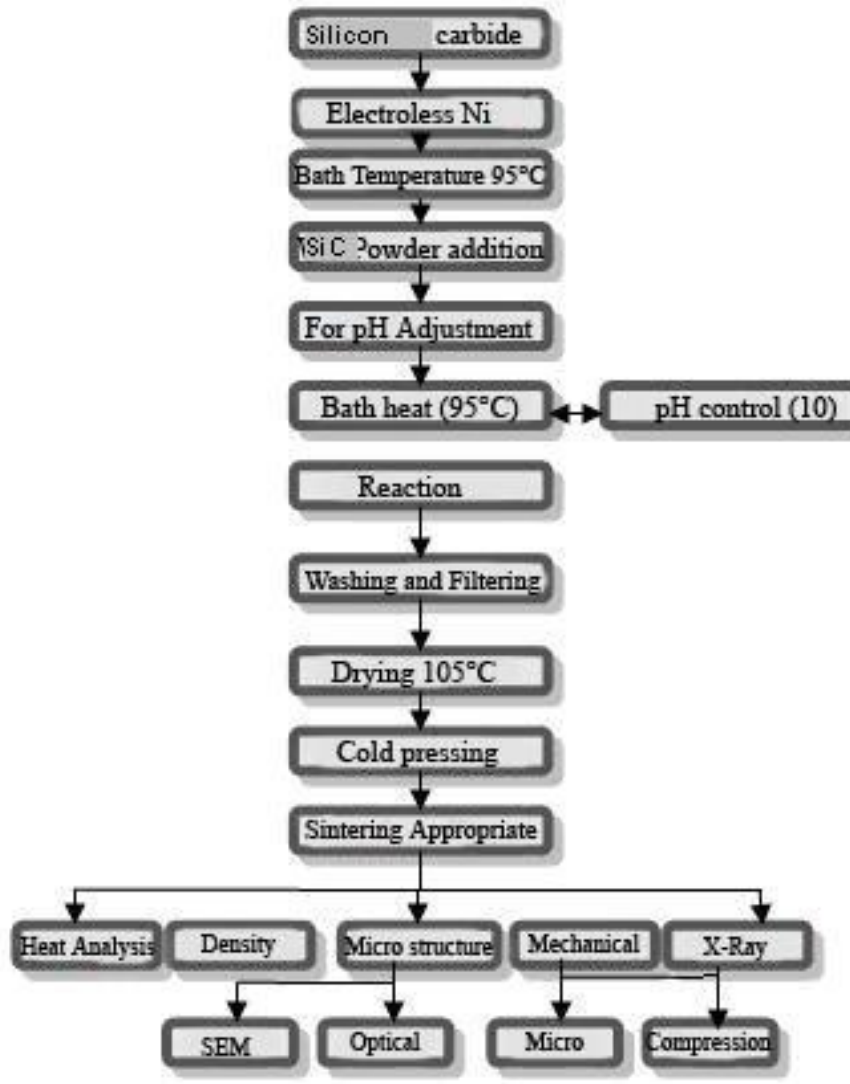

Figure 1. Experimental study flow diagram

In order to use sintering, Industrial sintering furnace was used. Furnace Phoenix brand $2450 \mathrm{MHz} 1500 \mathrm{~W} 230 \mathrm{~V}$ has label values. Sintering furnaces were produced in microwave sintering furnace at temperatures of $500-900{ }^{\circ} \mathrm{C}$ for 1 hour. SEM-EDX analyzes were performed after sanding and polishing the sintered samples. SEM photographs were taken with LEO143OVP Röntech device. In addition, a Shimadzu-AG / IS 100kN tester was used to measure the compressive strength of the samples.

Micro hardness of the samples was measured with the Shimadzu HMV 2 L micro hardness tester. The hardness values were determined by taking the average of the hardness values taken from 10 different areas for each sample in the micro hardness measurements applied to the samples.

\section{Experimental Findings}

In this study, the samples prepared and shaped by two different methods were sintered in the industrial microwave sintering furnace at temperatures ranging from $500^{\circ} \mathrm{C}$ to $900^{\circ} \mathrm{C}$. The samples were tested by making them ready for physical, mechanical and metallographic analyzes. In the study, the samples prepared and shaped (pressed) through two different methods were sintered at temperatures ranging from $500^{\circ} \mathrm{C}$ to $900^{\circ} \mathrm{C}$ in microwave furnace and made ready for physical, mechanical and metallographic analyses.

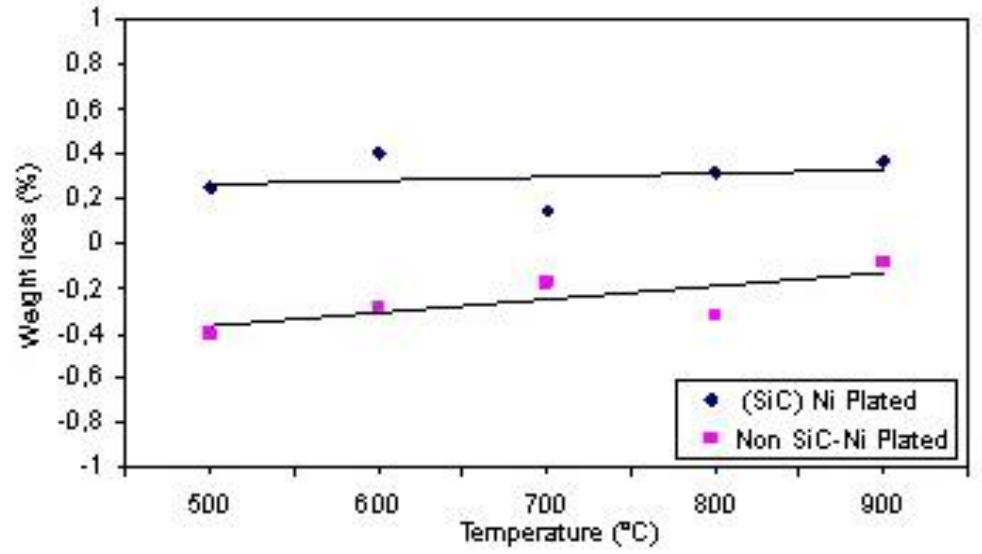

Figure 2. Percent weight change in the sintered samples depending on the temperature 
Density-temperature change graphic is shown in Figure 3. The pre-sintering raw density of the plated sample was estimated to be $4.21 \mathrm{gr} / \mathrm{cm}^{3}$. The highest post-sintering density was achieved at $700{ }^{\circ} \mathrm{C}$ as $4.57 \mathrm{gr} / \mathrm{cm}^{3}$. The highest post-sintering density of the non-plated sample was obtained at $700^{\circ} \mathrm{C}$. The pre-sintering density of the non-plated density was estimated to be $4.85 \mathrm{gr} / \mathrm{cm}^{3}$. The highest post-sintering density was observed to be $5.34 \mathrm{gr} / \mathrm{cm}^{3}$ at $700^{\circ} \mathrm{C}$.



Figure 3. The graphic of density change depending on the temperature

\subsection{Analysis of the Physical Properties of the Samples}

In this study, Two different methods were used to produce SiC reinforced composite samples in composite production. pre and post sintering density of the samples were determined. Figure 2 is a graph showing the weight change of samples produced by a mixture of sintered samples and powders by coating depending on the temperature. Ni weight loss occurred in the samples produced by coating and weight increase occurred in the uncoated sample. This showed that uncoated samples were more easily oxidized and that sintering was not good despite the use of argon atmosphere.

\subsection{Analysis of the Mechanical Properties of the Samples}

The compression strength and microhardness of the ceramic-metal composite material produced by powder mixing and nonelectric Ni coating methods were measured. The relationship between the sintering temperatures and compression strength values of the produced samples is given in Figure 5.



Figure 5. Compression strength test applied to the samples sintered at different temperatures

The microhardness-temperature change graph of the samples produced by mixing the powders and using the electro-current Ni coating methods is given in Figure 6. Micro hardness values of the produced composite samples, SiC powders were coated with $\mathrm{Ni}$ coating method without electric current. Produced samples were made using microwave sintering furnace at temperatures between 500-900 ${ }^{\circ} \mathrm{C}$. Samples produced using SiC-Ni powders and the Electroless Ni coating method were subjected to mechanical tests after sintering at $500-900^{\circ} \mathrm{C}$. 
The highest micro hardness value of the composite samples produced by using the Ni-Finite method without electric current was measured as $136 \mathrm{HV}$ at $900^{\circ} \mathrm{C}$. Microhardness of samples produced by using electroless Ni plating method gave higher results than mixing of SiC-Ni powders. The highest micro hardness of the samples produced by using electroless Ni plating method was measured as $148 \mathrm{HV}$ in sintered composite samples at $800^{\circ} \mathrm{C}$.

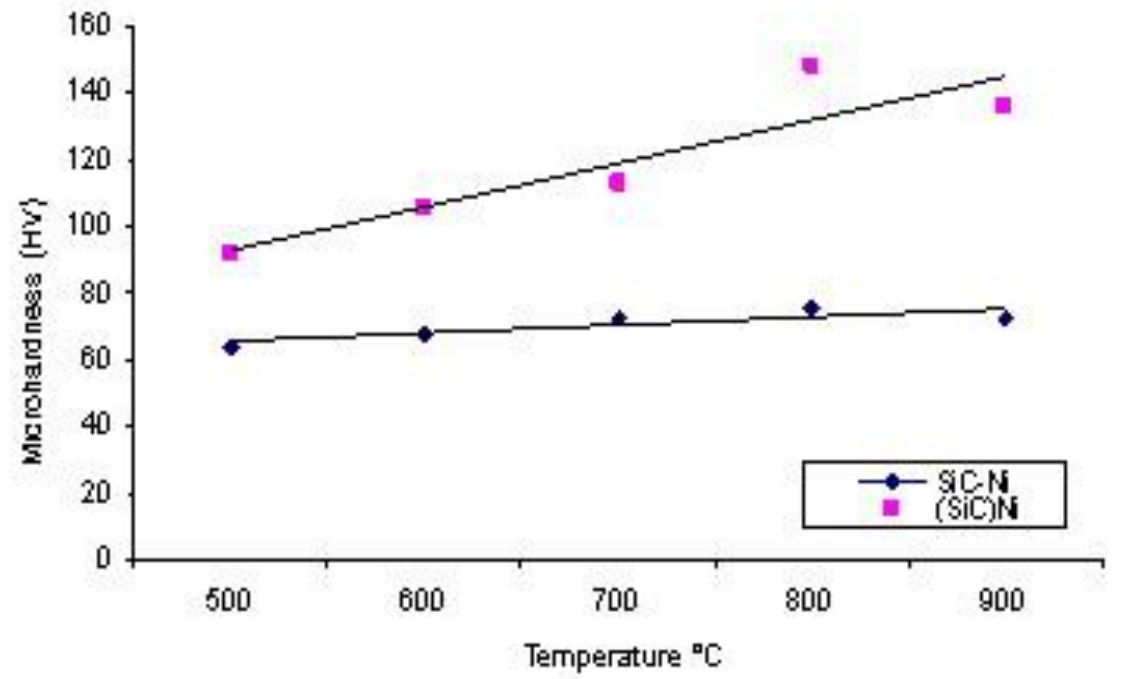

Figure 6. Microhardness - Temperatures curve of different product method.

\subsection{Metallographic Analysis}

Speciemes after the sintering of $\mathrm{SiC}-\mathrm{Ni}$ powders and the samples produced by using electroless Ni plating method, surface polishing processes were performed. After the electroless nickel plating process, it was examined by applying SEM EDX analysis whether Ni coating was applied to the powders. Fig. 7 shows the enlarged SEM images of ceramic-metal composite samples obtained from non-electric Ni-coated ( $\mathrm{SiC}$ ) powders and sintered at $800^{\circ} \mathrm{C}$ at different scales. In Figures $7 \mathrm{a}$ and $\mathrm{b}$, it was observed that the particles were better bonded to each other in the $\mathrm{Ni}(\mathrm{SiC})$ composite sample and the particles were larger. In the SEM image, there were pores with homogenous distribution between the grains.

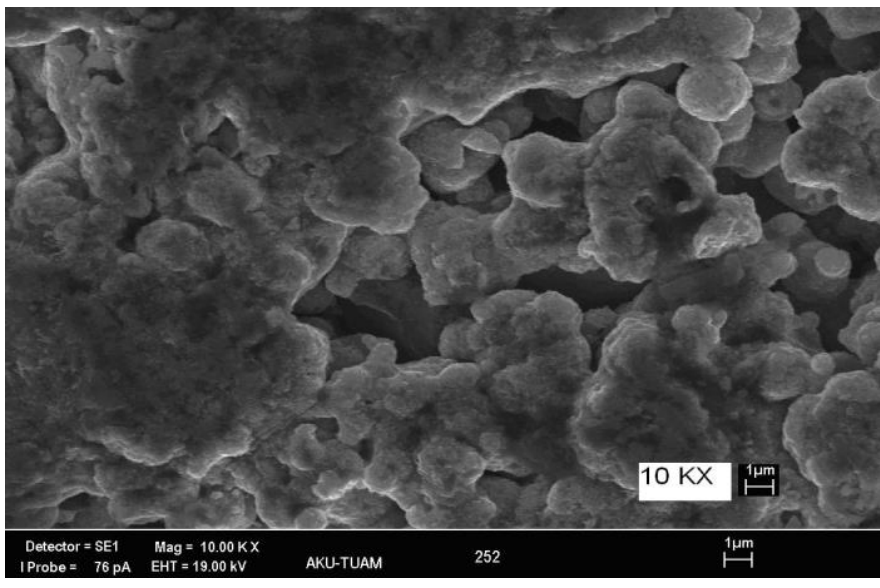

(a)

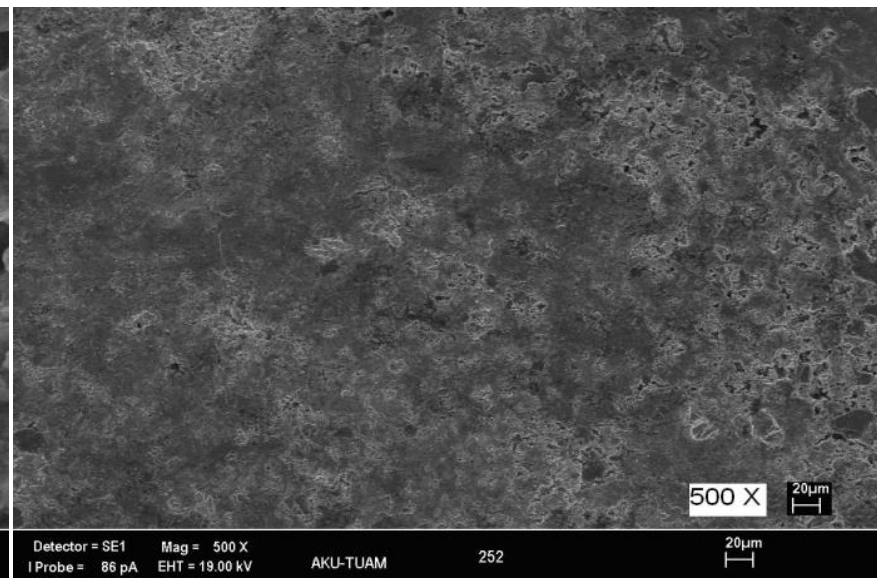

(b)

Figure 7. SEM view of (SiC)Ni composite at $800^{\circ} \mathrm{C}$

The SEM images of the composite samples produced by sintering at $900{ }^{\circ} \mathrm{C}$ by mixing the $\mathrm{SiC}$ and Ni powders are given in Figure 8a-b. Figure 8a shows the SEM image of the WC-Ni composite at 500X magnification. In Figure 8b, the 10kX magnified SiC particle is clearly visible.. 


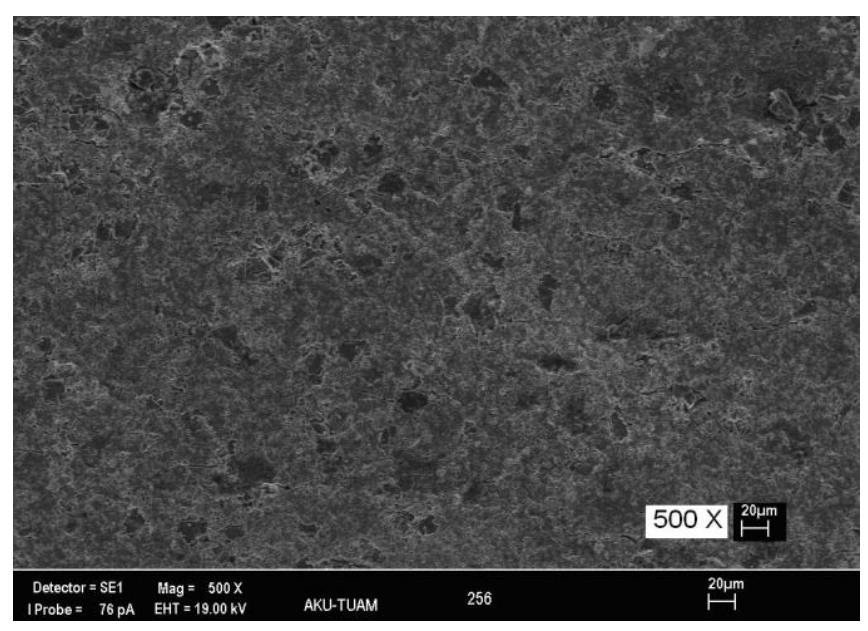

(a)

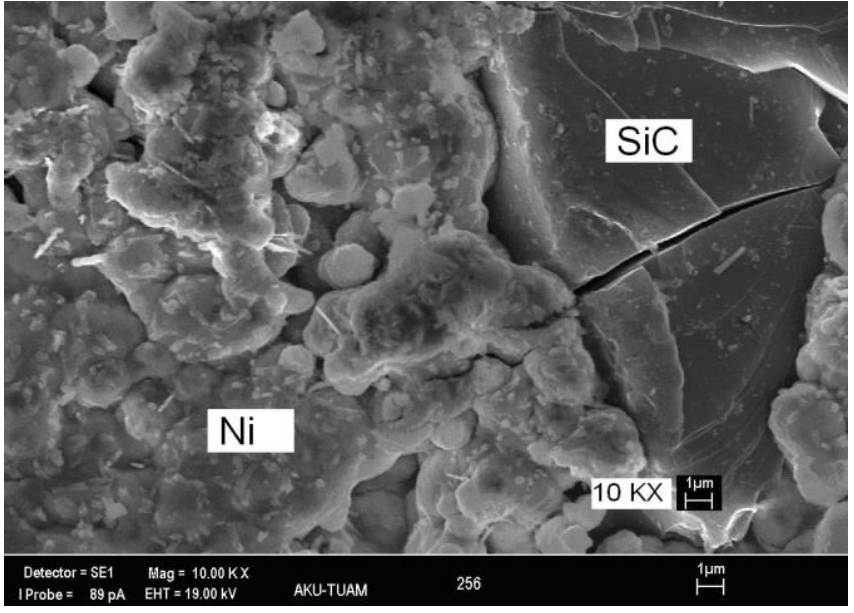

(b)

Figure 8. SEM view of SiC-Ni composite at $900^{\circ} \mathrm{C}$

\subsection{XRD Analysis}

In Figure 9, shows the peaks of $\mathrm{SiC}$ and $\mathrm{Ni}$ phases. In the sintered composite sample ( $\mathrm{SiC})$ at the microwave oven at $800^{\circ} \mathrm{C}$ the XRD graph of the Ni composite is given. Since the sintering takes place at low temperature, no different phase is formed.

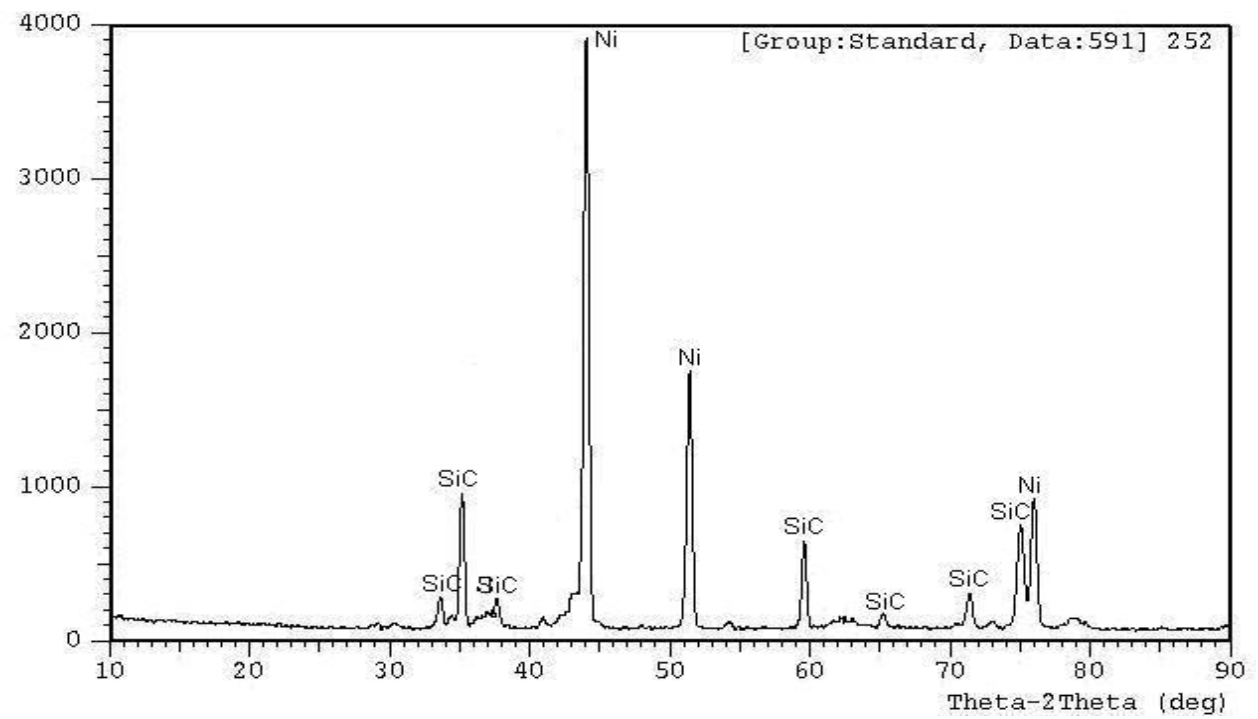

Figure 9. The XRD graphic of Nickel Plated SiC composite Sintered in Microwave Furnace at $800^{\circ} \mathrm{C}$

\section{Results \& Discussion}

As a result of the mechanical and metallographic tests applied to SiC-Ni composite samples, the following findings were obtained.

- In samples sintered at $900^{\circ} \mathrm{C}$, the average hardness value of the Ni-coated $\mathrm{SiC}$ after sintering was measured as $89.85 \mathrm{HV}$.

- The highest compressive strength was obtained as $22.24 \mathrm{MPa}$ at $900^{\circ} \mathrm{C}$ (Fig. 5).

- The highest density of composite samples produced in sintered $\mathrm{Ni}$ coated $\mathrm{SiC}$ powders at different temperatures was $4.57 \mathrm{gr} /$ $\mathrm{cm} 3$ at $700^{\circ} \mathrm{C}$ (See Figure 1). In the coated samples, the pre-sintering density was calculated to be $4.21 \mathrm{~g} / \mathrm{cm} 3$.

- The density before sintering in uncoated samples was calculated as $4.85 \mathrm{gr} / \mathrm{cm} 3$. The highest density after sintering was 5.34 $\mathrm{g} / \mathrm{cm}^{3}$ at $700{ }^{\circ} \mathrm{C}$.

- In the composite samples produced by using electroles Ni plating method, the highest micro hardness was measured as $148 \mathrm{HV}$ at $800^{\circ} \mathrm{C}$. The highest microhardness values of the samples produced by mixing the powders were measured as $37.8 \mathrm{HV}$ at $700^{\circ}$ C.

- It has been determined that composite samples produced by using electroless Ni coating method have more homogeneous microstructures and less pores.

It has also been found that the mechanical properties of the coated samples produced using the electroplating Ni coating method are higher than those of the uncoated samples. 
It has been concluded that $\mathrm{SiC}$ powders give a positive result to Ni-coating and microwave sintering method is more advantageous than classical sintering technique because of temperature, duration and low energy consumption.

\section{Acknowledgements}

We would like to extend our thanks to the Scientific and Technological Research Council of Turkey (TUBITAK) due to its contributions to this study with project no. 106T744.

\section{Referanslar}

Chatterjee A., Tanmay B., and K. G. Ayappa, (1998) 'Analysis of Microwave Sintering of Ceramics' Materials, Interfaces, and Electrochemical Phenomena October 1998 Vol. 44, No. 10

Chen Y., Cao M.,, Xu Q., Zhu J., (2**3) 'Electroless nickel plating on silicon carbide nanoparticles' Surface and Coatings Technology 172, 90-94

Changhong Dai and Xianpeng Zhang , (1997) "Microwave Synthesis of Ultrafine Silicon Carbide Whiskers" J.Am.Ceram Soc. 80 [5] 1274-1276

Horatiu Niciu and others (2007). 'The $\mathrm{SiC}-\mathrm{SiO}_{2}-\mathrm{Al}_{2} \mathrm{O}_{3}-\mathrm{Al}_{6} \mathrm{Si}_{2} \mathrm{O}_{13}$ Ceramic Composites Microwave Heating' Ceex 2007 Conference

Jarząbek, D. M.,Milczarek, M., Wojciechowski, T., Dziekoński, C., Chmielewski, M., 2017. Theeffect of metal coatings on the interfacial bonding strength of ceramics to copper in sintered $\mathrm{Cu}-\mathrm{SiC}$ composites, Ceramics International, 43, 5283-5291

Kidder, T. (1981). The soul of a new machine. Boston, MA: Little, Brown \& Company.

Malecki, A. And Micek-Ilnicka, A., 2000. Electroless nickel plating from acid bath, Surface and Coatings Technology, $72-77$.

Mandal S, Seal A, Dalu1, S K., Dey, A K., Ghatak S and Mukhopadhyay A K., (2001)'Mechanical characteristics of microwave sintered silicon carbide’ Bull. Mater. Sci., Vol. 24, No. 2, April 2001, pp. 121-124.

Somiya, S.; Inomata, Y., Silicon Carbide Ceramics, Ed. Elsevier Applied Science, 1991

Söyler, M., 2007. Toz metalurjisi ve uygulamaları, Yüksek Lisans Tezi, Tasarım ve İmalat Mühendisliği Anabilim Dalı, Gebze İleri Teknoloji Enstitüsü Mühendislik ve Fen Bilimleri Enstitüsü, Gebze-Kocaeli.

Sverdel V. V. , Shatov A. V., Yurchuk N. A. and Bakun O. V. , (1995)'Finely disperse cemented carbides WC-Ni I. Mechanical properties', Powder Metallurgy and Metal Ceramics, Volume 33, Numbers 1-2 / January,

Tang, F., Anderson, I.E., Biner, S.B., 2003. Microstructures and mechanical properties of pure Al matrix composites reinforced by $\mathrm{Al}-\mathrm{Cu}-\mathrm{Fe}$ alloy particles, Materials Science and Engineering A, 363, $20-29$.

Yönetken, A., 2017. Production and investigation of ceramic metal composite from electroless Ni plated AlN and Al powders, International Journal of Innovative Research in Science, Engineering andTechnology, 6 (10), 21-26.

Wu, G.,Zhang Q., Yanga, X., Huanga Z. \&Sha, W., 2014. Effects of particle/matrix interface and strengthening mechanisms on the mechanical properties of metal matrix composites, Composite Interfaces, 21(5 ), 415-429.

Zhang Q., Wu1, M., and Z. Wen, (2005) 'Electroless nickel plating on hollow glass microspheres' 'Surface \& Coatings Technology' $192213-219$ 